\title{
Tourism and economic growth in Greece: An ARDL bound testing approach in a Kaldorian framework
}

\section{KONSTANTINOS SPINTHIROPOULOS $^{1 *}$ (D), CHRISTOS NIKAS $^{1}$ (D) and ELENI ZAFEIRIOU ${ }^{2}$ (D)}

\footnotetext{
${ }^{1}$ Department of International and European Studies, University of Macedonia, Thessaloniki, Greece

${ }^{2}$ Department of Agricultural Development, Democritus University of Thrace, Xanthi, Greece
}

Received: February 19, 2018 • Revised manuscript received: May 17, 2018 • Accepted: May 26, 2018

(c) 2020 Akadémiai Kiadó, Budapest

\begin{abstract}
The purpose of the study is to examine the relationship between tourism development and economic growth in Greece, using the Autoregressive Distributed Lag (ARDL)-Bounds testing procedure. The present paper attempts to examine the relevance of the tourism led growth hypothesis according to the Kaldorian theory. The analysis was carried out for the period from 1963 to 2016 and involves the short-run as well as the log-run impact. As a proxy for the output of the tourism sector, its receipts are employed, while as an index for economic growth, the GDP is employed. The empirical results show that the economy of Greece can recover and return to the long-run equilibrium with a speed of adjustment $7.17 \%$ per year.
\end{abstract}

\section{KEYWORDS}

Kaldorian growth theory, tourism, ARDL, bound testing, Greece

JEL CODES

010, C32, L83, 040, 040, 047, 013, C1, C24, Z32

\footnotetext{
* Corresponding author. School of Economics, Department of Management Science \& Technology, University of West Macedonia, and Technological Educational Institute of Western Macedonia (TEIWM), Koila, Kozani, 50100, Greece. E-mail: spinthiropoulos@gmail.com
} 


\section{INTRODUCTION}

Within the last four decades, agriculture as a source of income for Greek families has become less and less important, while the share of tourism - and the service sector in general - has been on the rise (Delivani 1991; NSAG 2017). Economists around the World investigate the role of tourism as a promoter of economic growth in the short as well as in the long term, the so-called tourism led growth hypothesis (Shan - Wilson 2001; Brida - Pulina 2017). Furthermore, Belloumi (2010) showed that the development of tourism leads to an increase in the inflow of foreign exchange revenues, contributing positively to the overall balance of payments.

According to the World Tourism Organization (WTO), tourism receipts of Greece increased from 3.8 billion US dollars in 1996 to 17.3 billion US dollars by 2015, growing at an average annual rate of $9.7 \%$. It is generally known that there are difficulties in measuring the tourism sector in relation to other sectors, like the primary sector and the manufacturing sector. Katrakilidis et al. (2013) were attracted by the Kaldorian theory and tried to investigate the validity of the Kaldorian insights into the economic growth and manufacturing. The assumptions of the Kaldorian theory and the results of their research paper verify the validity of this theory while a positive relation between the manufacturing production and GDP growth for Greece was confirmed.

The Kaldorian theory (Kaldor 1966) was introduced to investigate the economic growth for countries in the process of industrialization. ${ }^{1}$ By using the basic principles of the Kaldorian theory, researchers used the growth of tourism and other variables, like constructions instead of manufacturing as the explanatory variables. For example, Delivani (1991) employed tourism instead of manufacturing in order to examine the intertemporal relationship between tourism and growth. She concluded that numerous small countries with high per capita GDP growth rate were specialized in tourism. Schubert et al. (2010) argued that while the top 10 nations were ranked according to the contribution of the tertiary sector, and especially, tourism activity, these are all small islands.

A rapid growth in the tourism sector was observed in the case of Greece within the last decades. Greece is a developing country that offers numerous tourism destinations, mountain ranges, historical and archaeological sites. Greece has only one region that is not touched by the sea, Western Macedonia. However, religion and winter tourism are also blooming in this region.

The ongoing overall economic crisis in Greece did not prevent the tourism sector from expanding. Of course, the extended economic downturn has led many people to unemployment as in other sectors of the economy, such as the primary sector of production. Regardless of the continuing economic recession, tourism is perhaps the only business sector that continued to grow in Greece Table 2. At the same time, a large part of the unemployed human resources also find employment in the primary sector. In other words, the tourism sector and the exploitation of agricultural land have led to the decline of the unemployment rate in the prolonged years of the economic crisis in the country. This is shown by the direct contribution of travel \& tourism to GDP, which was EUR 13.2 billion, 7.5\% of total GDP in 2016 and is forecast to rise by $7.5 \%$ in 2017 , and to further rise by $4.5 \%$ annually from $2017-2027$, to EUR 22.1 billion, $9.6 \%$ of total

\footnotetext{
${ }^{1}$ The relevance of the Kaldorian growth theory was the subject of a Conference entirely dedicated to Kaldor's oeuvre. The 11 best papers were published in the 2017 Special Issue of Acta Oeconomica (Vol. 67.). (Editor's note).
} 
GDP in 2027 (WTTC 2017). The total contribution of travel \& tourism to GDP was EUR 32.8 billion, $18.6 \%$ of GDP in 2016 , and is forecast to rise by $6.9 \%$ in 2017 , and to rise by $4.6 \%$ per annum to EUR 54.7 billion, 23.8\% of GDP in 2027.

The contribution of tourism to the Greek economy, as presented above, prompts us to agree with Delivani - Nikas (2013). They argued that the "engine of growth" for Greece was not the manufacturing sector but the tertiary sector, and especially, the tourism sector. They confirmed that the implementation of the Kaldorian theory was possible when the tourism sector was the starting point for the economy.

At this point, it is worth recalling that the tourism industry is adversely affected by unexpected factors, such as earthquakes, extreme weather conditions, war and terrorism. In any case, in order to increase tourism demand, terrorism should be overcome in tourist destinations. While tourism is the only "heavy industry" of the Greek economy, possible terrorist activities will be the reason for reducing tourism receipts. Samitas et al. (2018) point out the negative effect of terrorism on tourism demand using Greece as a case study.

\section{LITERATURE REVIEW}

Different approaches have been used to examine the effect of tourism on GDP. What stands out amongst the most well-known methodologies in this field is the cointegration method. This technique was presented by Engle - Granger (1987) and has become a useful method in avoiding spurious regression when working with non stationary time series data. The present study attempts to investigate the relationship among tourism receipts with GDP for Greece during the period of 1963-2016 by using the Autoregressive Distributed Lag (ARDL) method. The ARDL method was introduced by Pesaran - Shin $(1995,1999)$. According to this method, it is not obligatory for all variables to be integrated in the same order. Additionally, this method is not affected by the size of the sample.

Several studies also focus on the fact that tourism development leads to economic growth. Balaguer - Cantavella-Jorda (2002) found that there is a stable long-run relationship between economic growth and tourism expansion for Spain. Dritsakis (2004) found evidence of a bidirectional causal relationship between international tourism and economic growth for Greece. He applied a co-integration test suggested by Johansen (1995) and the causality test proposed by Granger (1988), using an error-correction model.

Gunduz - Hatemi (2005) by using a different method tried to examine the contribution of tourism to the economic growth in Turkey. The validation of their research was made with the use of the leveraged bootstrap causality test. Through the use of this method it was concluded that the tourism led growth hypothesis is supported empirically in Turkey. In the same vein, Wickremasinghe - Ihalanayake (2006), while examining the causality between tourism and economic growth in Sri Lanka, found that there was a significant causal relationship between tourism receipts and GDP, by using multivariate cointegration, error correction modelling and variance decomposition analysis.

The use of the Granger causality test, based on the vector error correction method (VECM), has been widely used to examine the relationship between two or more variables. There are many researchers who have used the above method in order to arrive at safe conclusions. 
In a study by Zortuk (2009), the relationship between the expansion of tourism and economic growth in Turkey was examined, employing the Granger causality test based on VECM. He concluded that there is a unidirectional causality from tourism development to economic development in Turkey. Belloumi (2010) also found a positive and unidirectional causal relationship between economic growth and tourism by using a trivariate model.

Many researchers recommended that governments should focus on economic policies in order to promote international tourism. In particular, they supported existence of a unidirectional causality from tourism earnings to economic growth.

In any case, several researchers supported that both tourism and economic growth Grangercause each other. Ongan - Demiroz (2005), while analysing the long-run contribution of tourism to the economic growth in Turkey, found that there is a bidirectional causality between worldwide tourism and financial development. In the same vein, Katircioglu (2009) examined the nexus between tourism and economic growth in Turkey by using bounds testing and the Johansen Juselius (JJ) cointegration method and found no causal relationship between tourism and economic growth.

Brida et al. (2008) attempted to investigate a possible relationship between tourism spending and real exchange rate with economic growth for Mexico. Using the Granger test (a modified version of the Granger Causality test), they studied a possible causality relationship and found that there was a unidirectional causality between tourism spending and real GDP.

Beyond the positive relationship between tourism industry and economic growth, Webster Ivanov (2014) have gone one step further by indicating that a growing tourism industry can also be used as a catalyst for political stability. However, as the overall contribution of tourism receipts to GDP of Greece is positive, it is easier to achieve political stability in a country that has suffered a deep economic downturn over the last eight years.

\subsection{The Kaldorian Theory: Manufacturing or services?}

In order to explain the growth of countries in the procedure of industrialisation, or in general, the transition from an agriculture-based economy to an economy mainly based on industry, the Kaldorian Theory was adopted. The supremacy of the manufacturing sector compared to the other two sectors of the economy exists due to its ability to expand by absorbing resources (mainly labour) from less productive primary and tertiary sectors (Kaldor 1966).

This dynamism, combined with the introduction of new production methods, technology and innovation, high specialisation, expanding markets and strong forward and backward linkages, are all considered as exclusive privileges of the industry, and have made the growth of manufacturing looks like an endless process. Especially if manufacturing could adapt to the changing economic environment, it could maintain the development of the economy forever.

It has been shown that the manufacturing sector, in many cases, has not led to economic growth. When this driving sector finally reached the point of "economic maturity" it then generally starts the deindustrialisation process and, therefore, strengthens the tertiary sector (Rowthorn - Wells 1987; Hare 2019). This is exactly what happened to many European industrial countries during the 1970s leading to a re-opening of the discussion on whether sectors other than manufacturing could prove to be alternative engines of growth.

Over the past decades the implementation of the Kaldorian theory was one of the most notable trends in economic analysis. Drakopoulos - Theodosius (1991) and Katrakilidis et al. 
(2013) proceeded to investigate the validity of the Kaldorian theory. They tested the three laws of the Kaldor's theory and its relevance to the Greek economy for the period of 1970-2006, based on the ARDL method. The results of their surveys showed the verification of the basic assumptions of the Kaldorian theory between manufacturing production and GDP growth for Greece. The extent of their data and the procedure used was generally accepted.

Delivani (1991) and Delivani - Nikas (2013) argued that the "engine of growth" for Greece was not the manufacturing but the tourism sector. This view came in stark contrast to the results of Drakopoulos -Theodosiou (1991) and Katrakilidis et al. (2013) and provided a motive for further research in order to point out the importance of the tourism and primary sector instead of the manufacturing sector in Greece.

In this study, we will investigate the contribution of the tertiary sector, and especially, tourism to economic growth using ARDL Bound testing econometric approach. We proceeded with a different approach in order to study the relation among tourism receipts and the GDP of Greece.

The present paper aims at a different approach of the Kaldorian theory for the case of Greece. Tourism and primary production will be tested as an alternative Kaldorian "engines of growth" using ARDL Bound testing approach. This country has experienced a high GDP growth (since the early 1970s and up to 2008 with a short interval in the late 1970s) and unprecedented negative growth rates (up to $-16 \%$ ) after 2008 .

In the third section, the methodology of this study and the data employed are analysed. In the fourth section, the results of this study are presented and discussed. The final section refers to the conclusions and policy recommendations.

\section{ECONOMETRIC FRAMEWORK OF OUR RESEARCH}

The present work intends to study the relationship among GDP in Greece, net value added generated by agriculture, and finally, the receipts generated by tourism as a proxy for GDP generated by tourism.

The model to be estimated is the following (Eq 1):

$$
\ln (G D P)=a_{1} \ln \left(G D P_{\text {agr }}\right)+a_{2} \ln \left(G D P_{\text {tour }}\right)
$$

where GDP and net value added generated by agriculture are derived by World Development Indicators and the World Bank for the period of 1963-2016, and additionally, the receipts by tourism used as a proxy for GDP generated by tourism are derived by the National Bank of Greece.

The ARDL approach to cointegration is employed in the present study. The major advantage of this methodology, compared to the Juselius approach, is its flexibility to be applied on different integration order variables (Pesaran - Pesaran 1997). In addition, the model estimation with this approach results in the selection of sufficient lags for the data generating process within the general-to-specific modelling framework (Laurenceson - Chai 2003). The Error Correction Model generated with the ARDL procedure employs only a single reduced form equation, while the conventional cointegration procedures estimate the long-run relationship within a context of system equations (Ozturk - Acaravci 2011). 
The issue of endogeneity in the model estimation is a minor problem under the condition that the estimated model is free from residual correlation. The implementation of the methodology demands for the satisfaction of one condition that is to exclude the use of the series being I(2). To be more specific, in case the time series are I(2) then the critical bounds provided by Pesaran et al. (2001) and Narayan (2005) are not valid. For that reason, the unit root test is a pre-condition, in order for the variables to satisfy the underlying assumptions of the ARDL bounds testing approach of cointegration methodology. Therefore, two types of unit root tests are used to determine the order of integration: (i) unit root test without structural break (Dickey-Fuller (DF) - generalized least squares (GLS) technic is employed), and (ii) unit root tests with structural breaks. The DF - GLS unit root test is employed to check stationarity in the data and was introduced by Elliot et al. (1996). This test is considered to be more efficient and with higher power compared to the augmented D-F or Phillipps - Perron unit root tests, especially when the time series under review are marginally non-stationary.

The implementation of the ARDL approach involves two steps in order to estimate the existence of a long-run relationship. The first step is to investigate the existence of a long-run relationship among the variables of the equation. The model for the standard log-linear functional specification of the long-run relationship between GDP of Greece, net value added generated by domestic agriculture and receipts from tourism for the same country may follow $\Delta G D P_{t}=a_{1}+$ as (Eq 2):

$$
\begin{aligned}
\Delta G D P= & a_{1}+\sum_{i=0}^{p 1} \phi_{1 i} G D P_{a g r}+\sum_{j=1}^{q 1} \theta_{1 i} G D P+\sum_{l=0}^{n 1} \beta_{1 i} G D P_{\text {tour }_{t-j}}+a_{1} G D P_{\text {agr }_{t-1}}+a_{2} G D P_{\text {tour }_{t-1}} \\
& +a_{3} G D P_{t-1}
\end{aligned}
$$

The next step in our analysis involves the computation of the values of the F-statistics of the estimated ARDL model, for testing the existence of a long-run relationship among the variables under the null hypothesis. The F-statistics are compared with the critical bounds of Pesaran et al. (2001). The bounds test result is related to the selection of the lag order, p. Therefore, we estimate the conditional model by imposing a maximum of four lags on the model and using Akaike Criterion (Akaike) to select the optimum number of lags. The null hypothesis that no long-run relationship among GDP, net value added generated by agriculture and GDP generated by tourism exists is conclusively rejected and the serial correlation-free residuals are achieved with the lag order of three $(\mathrm{p}=3)$, as suggested by the Akaike criterion.

To validate the existence of cointegration, we estimate the Unrestricted Error Correction Model (UECM). The lag selection, through which the data generating process is captured, is based on the general-to-specific framework (Laurenceson - Chai 2003).

The ARDL model employed is, however, slightly modified in an appropriate way in order to correct the residual serial correlation and the endogeneity problems simultaneously (Pesaran Shin 1999). The following UECM is used for our purpose.

$$
\begin{aligned}
\Delta \ln G D P_{t}= & c_{1+}+c_{2} T+\beta_{1} \ln G D P_{\text {agrt }-1}+\beta_{2} \ln G D P_{\text {tourt }-1}+\beta_{3} \ln G D P_{t-1} \\
& +\sum_{i=1}^{p} \beta_{3 i} \Delta \ln G D P_{\text {tourt }-i}+\sum_{i=1}^{p} \beta_{4 i} \Delta \ln G D P_{t-i}+\sum_{i=1}^{p} \beta_{5 i} G D P_{\text {tagr }_{t-1}}+u_{t}
\end{aligned}
$$

where $G D P_{t}$ denotes GDP (G1), GDP $P_{\text {agrt-1 }}$ denotes value added generated by agriculture (GAGR), GDP tourt $-1_{1}$ denotes tourism receipts (G2), T denotes the time trend, $c_{1}$ the constant, G1, G2, GAGR are the acronyms used in the econometric analysis, $\beta_{1,2,3}$ denote the long-run 
coefficients, $\beta_{3 i}, \beta_{4 i}, \beta_{51}$ denote the short run parameters, $\Delta$ denotes the first difference operator of the variable employed and $\mathrm{p}$ denotes the lags determined by the lag length optimization criteria, such as Akaike Information Criterion (AIC) and Schwarz Bayesian Criterion (SBC).

In Equation (3), we may identify the long term as well as the short-term parameters. To be more specific, $\beta_{1}, \beta_{2}, \beta_{3}$ represent the long-term parameters while rejecting the null hypothesis, $\beta_{1}=\beta_{2}=\beta_{3}=0$ (equivalent to no cointegration) against the alternate according to which $\beta_{1} \neq$ $\beta_{2} \neq \beta_{3} \neq 0$ (implies that the variables are cointegrated). The test for cointegration is based on the computed F-statistic compared to the values of the tabulated critical bounds. The upper critical bound (UCB) is employed under the condition that the regressors are I (1) or I (0) while the lower critical bound is used only under the condition that they are I (0). The critical values used in the present study were introduced by Narayan (2005). The potential results of the test are the following:

1. If the F - statistic exceeds the UCB, cointegration is confirmed.

2. In case the F statistic is less than the lower Critical Value, the null hypothesis of no cointegration is confirmed.

3. An area of uncertainty is determined within the two critical bounds, a case in which our decision is relied on the lagged error correction term for a long-run relationship.

Having established the existence of cointegration, the long-run relationship for the ARDL (p, q, r) model (Equation 4) is provided by the following formula;

$$
\ln G D P_{t}=c_{1}+\sum_{i=1}^{p} \beta_{1} \ln G D P_{t-i}+\sum_{i=0}^{q} \beta_{2} \ln G D P_{a g r_{t-i 2}}+\sum_{i=0}^{r} \beta_{3} \ln G D P_{\text {tourt }-i}+\beta_{4} T+u_{t}
$$

Equation (3) also includes the short run dynamics, for which also sensitivity test, parameter stability and goodness of fit using cumulative sum of squares of recursive residuals (CUSUM) are implemented. For that reason, the short run dynamics is a necessity for testing the stability of the long-run coefficients based on Pesaran - Pesaran (1997).

\section{RESULTS - DISCUSSION}

The present paper makes an effort to survey the validity of the Kaldorian Theory for the country of Greece. The relationships between economic development, tourism and the primary production sector are investigated. In other words, the relation between the tertiarisation of the Greek economy and the economic development is investigated by using an ARDL model with bound testing approach.

Our methodology involves the implementation of a unit root test and in particular the DF GLS unit root test. According to the results of the DF-GLS test, we are confident that this is exactly the situation that was designed for the ARDL model simulation. Applying the unit root test for the first differences of each series has led us to the rejection of the zero hypothesis, meaning that the data is I (2). Since the data is I (0) or (1) and in no case I (2), we can proceed to the bound tests (Table 1).

As provided by the results of the DF - GLS test, all the time series are integrated of rank 1 since they are non-stationary in the level and stationery in the first differences. Since our variables are stationary at the first differences and none are I(2), this allows us to implement the 
Table 1. Results of DF-GLS unit root test

\begin{tabular}{|l|c|}
\hline Variables & $t$ - statistic \\
\hline $\mathrm{GDP}_{\mathrm{t}}^{-1}$ & $-5.23^{* * *}$ \\
\hline$\Delta \mathrm{GDP}_{\mathrm{t}}$ & $-11.02 * * *$ \\
\hline $\mathrm{GDP}_{\mathrm{ttour}}{ }^{-1}$ & -2.28 \\
\hline$\Delta \mathrm{C}_{\text {ttour }}$ & $-7.40^{* * *}$ \\
\hline $\mathrm{GDP}_{\mathrm{tGAGR}}{ }^{-1}$ & $-4.27^{* *}$ \\
\hline$\Delta \mathrm{C}_{\mathrm{tGAGR}}$ & $-5.47^{* * *}$ \\
\hline
\end{tabular}

Note: The critical values are $-3.86,-4.19,-4.73 *, * *, * * *$ denotes rejection of null hypothesis for 10,5 and $1 \%$, and, respectively (all the variables are in logarithmic form).

ARDL bounds testing approach to cointegration. The next step in our analysis involves the computation of the values of the F-statistics of the estimated ARDL model, for testing the existence of a long-run relationship among GDP in Greece, net value added generated by agriculture and the receipts generated by tourism, under the null hypothesis (according to which no relationship between the regressors exists).

With the assistance of bound testing as described in Pesaran et al. (2011), we detected the existence of a long-run relationship among the variables employed. Implicitly, our findings (Table 2) confirm the long-run relationship among the variables employed. Implicitly, our findings confirm the long-run relationship for the variables studied given that the $\mathrm{F}$ - statistic criterion is more than the Upper Bound value of Narayan's lower bound critical value at 1, 5, and $10 \%$ level of significance implying that the null hypothesis of no cointegration can be rejected. According to Pesaran - Pesaran (1997) bound testing ARDL model, we can reject the null hypothesis that the model's variables are zero jointly. Therefore, all the three-variables are found cointegrated with a common movement to the long-run equilibrium.

The estimation of the long-run parameters of the model is the next step in our analysis as outlined in Pesaran et al. (2001). The estimation results are provided in Table 3. Prior though, we should describe the ARDL model as selected by the Akaike criterion. To be more specific, for the case of Greece the model selected is ARDL $(1,1,2)$ (net value added per capita is the regressor). Furthermore, the long-run coefficients are found statistically significant at $10 \%$ level while their signs and the magnitudes are compatible with the existing economic theory.

Table 2. The results of Bounds testing to cointegration

\begin{tabular}{|l|c|c|c|}
\hline Country & Estimated model & F - statistics & Lags selected \\
\hline Greece & $\begin{array}{c}\Delta(\mathrm{GDP})=\Delta\left(\mathrm{GDP}_{\text {tour }}\right) \\
+\Delta\left(\mathrm{GDP}_{\mathrm{AGR}}\right)+\Delta\left(\mathrm{GDP}_{\mathrm{AGR}}(-1)\right)\end{array}$ & 11.82 & 2 \\
\hline
\end{tabular}

Note: Critical Value Bounds for $10 \%, 5 \%, 2.5 \%$ and $1 \%$ are for 10 Bound 2.17, 2.72, 3.22, 3.88 and for I1 Bound $3.19,3.83,4.50$ and 5.30 , respectively. 
Table 3. Estimation result for long-run relationship

\begin{tabular}{|l|c|c|c|}
\hline \multirow{2}{*}{ Greece } & \multicolumn{3}{|c|}{ Dependent variable $\Delta(\text { G1 })_{\text {Greece }}$} \\
\cline { 2 - 4 } & Variable & Coefficient & St. error \\
\hline ARDL $(1,1,2)$ & $\operatorname{GDP}(-1)$ & $0.071^{* * *}$ & 0.030 \\
\cline { 2 - 4 } & $\operatorname{GDP}_{\text {tour }}(-1)$ & $-0.015^{* * *}$ & 0.017 \\
\cline { 2 - 4 } & $\operatorname{GDP}_{\text {AGR }}(-1)$ & $-0.073^{* *}$ & 0.041 \\
\hline
\end{tabular}

Note: $* * *, * *, *$ denotes rejection of null hypothesis for 1,5 and $10 \%$ level of significance, respectively.

Additionally, the Error Correction Term (ECT) as provided in Table 4, has the expected sign (negative and statistically significant) indicating that any deviation from the long-run equilibrium between variables is corrected with an annual rate of about $7.17 \%$. This result indicates the existence of cointegration of the variables studied.

Regarding the short run dynamics, as observed in the error correction model in Table 4, the statistical significance of the variables employed in the study is confirmed. In particular, the findings for the coefficient estimates of all lagged first differenced variables in the ARDL model (short-run coefficient estimates) are indicative of the dynamic adjustment of all variables.

The next step in our analysis involve all the residuals diagnostic tests for heteroscedasticity, serial correlation and normality of the model estimated. According to our findings as illustrated in Table 5 no problems were validated for the liquidity preference money supply (LM) model estimated based on ARDL cointegration technique.

Next, we test the stability of the model estimates, and thus, we apply the cumulative sum (CUSUM)-squared test proposed by Brown et al. (1975) to the residuals of the model. The

Table 4. Error Correction Representation for the selected ARDL model

\begin{tabular}{|l|c|c|c|}
\hline \multirow{3}{*}{ Greece } & \multicolumn{3}{|c|}{ Dependent variable $\Delta \mathrm{G1}$ tGR } \\
\cline { 2 - 4 } & Regressor & Coefficient & St. error \\
\hline & $\Delta \mathrm{DP}_{\mathrm{tour}}$ & $0.1083^{* *}$ & 0.046485 \\
\cline { 2 - 4 } & $\Delta \mathrm{C}_{\mathrm{tGAGR}}$ & $0.505^{* *}$ & 0.080173 \\
\cline { 2 - 4 } & $\mathrm{Ecm}_{\mathrm{GRE}(\mathrm{t}-1)}$ & $0.071759 * * *$ & 0.011725 \\
\cline { 2 - 4 } & $\mathrm{Ect}_{\mathrm{GRE}(\mathrm{t}-1)}=\mathrm{G1}_{\mathrm{tGRE}}-\left(0.2229 * \mathrm{G} 2_{\mathrm{tGRE}}+1.0179 * \mathrm{G}_{\mathrm{tGAGR}}\right)$ \\
\cline { 2 - 3 } & \multicolumn{3}{|c|}{$\mathrm{AdjR}^{2}=69.6$} \\
\hline
\end{tabular}

Table 5. Diagnostic tests of the selected ARDL model

\begin{tabular}{|l|c|c|}
\hline $\mathrm{X}^{2}$ normal & $\mathrm{X}^{2}{ }_{\text {ARCH }}$ & $\mathrm{X}^{2}$ SERIAL \\
\hline $6.12(0.124)$ & $0.3037(0.624)$ & $0.6361(0.785)$ \\
\hline
\end{tabular}




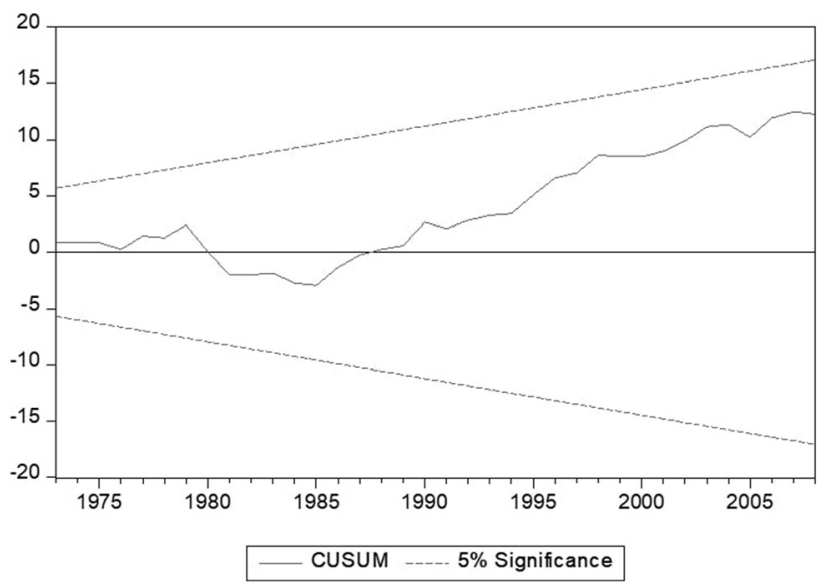

Figure 1. Results of CUSUM test for the time period studied

CUSUM test is based on the cumulative sum of recursive residuals based on the first set of $n$ observations. It is updated recursively and is plotted against the break points. If the plot of the CUSUM-squared test based on the squared recursive residuals lies within the $5 \%$ significance level, then the estimates are stable. As illustrated in Figs. 1 and 2 the plots of the CUSUMsquared statistics stay within the critical bounds confirming (represented by a pair of straight lines) the stability of the studied long-run estimates.

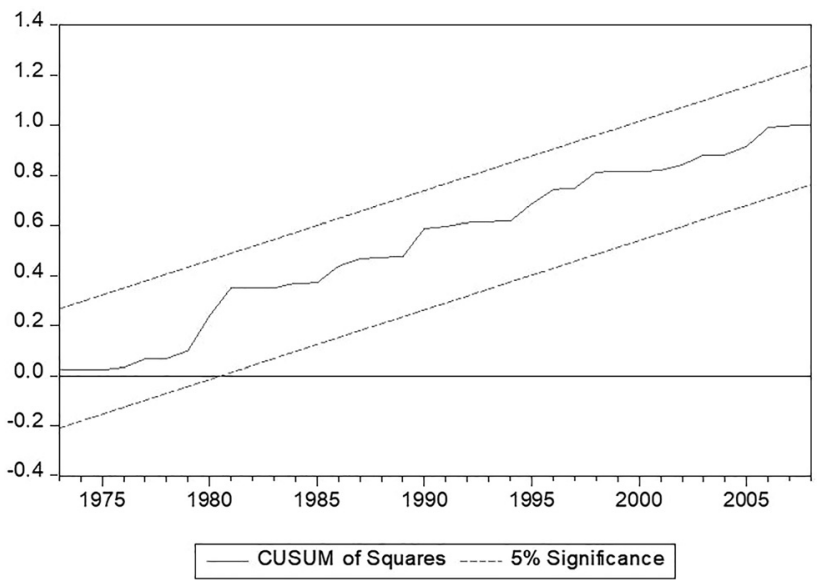

Figure 2. Results of CUSUM of squares tests for the time period studied 


\section{CONCLUSIONS}

The hypothesis that tourism is a growth engine has been a subject for several researchers around the world. Therefore, the variability of tourism necessitates the study of economic growth in terms of a country, or even region specific.

The present work studies the tourism led growth hypothesis in Greece, a country that is going through a severe crisis since the last decade. The intertemporal relationship is studied with the assistance of ARDL bound testing approach. The existence of the cointegration is validated for the variables studied while no problem of autocorrelation was detected. The short-run dynamics are also estimated. The results of our analysis confirm the long-run relationship between economic development and tourism. With the ARDL approach the investigation of the tertiarisation of the Greek economy has been confirmed. Thus, the contribution of tourism in the economic growth of Greece is a reality and tourism can adequately promote economic growth and become the major force to overcome the economic crisis.

The diversification of the tourism sector and the dynamism in relation to the other sectors of the Greek economy appeared particularly in the years of the prolonged economic recession. Tourism sector continued to grow in the years of the economic crisis, indicating that there is a possibility for further growth in this sector.

Basic statistical process control confirmed that apart from being an "engine of growth", tourism is a key source of employment, since 1 in 11 jobs globally are generated by this sector. By employing tourism as a main variable that causes economic growth instead of manufacturing, the results were remarkable for the Greek economy. We confirmed that, in small countries that are specialised in tourism industry, the Kaldorian theory is valid by establishing the tourism industry as the driving force of Greece.

These findings underline the need to invest in the tourism industry as a means of invigorating economic growth. At the same time, investments in agriculture are imperative because Greece, through the primary sector, can cover the needs of the population and at the same time reduce the unemployment rate.

The policy implications of our findings could be summarised as follows:

- The agricultural sector seems to have been abandoned too fast and carelessly in the case of Greece. Even though a massive return to farming would be a drawback from the modernisation of the economy. Our investigation has shown that this sector has a lot more to give in terms of output and employment, especially in terms of high-quality competitive products rather than commodities.

- In the context of a prolonged economic crisis, the growth potential of tourism in the case of Greece calls for policy measures to encourage the further development of this sector.

- On a long-term basis, improving the existing infrastructure, encouraging the implementation of new technologies, training of the staff and the management of tourist accommodation will be required if the tourism sector is to accomplish further enhancements in productivity.

- On a short-term basis, relieving tourism from heavy taxation should be seriously considered. Prolonged over-taxation affects tourism negatively as it has already affected the primary sector. Provided that the financial stability of Greece continues and the 
target for primary budget surpluses over 3\% annually is gradually relaxed, the policymakers should reduce those taxes that negatively influence tourism as a matter of top priority.

\section{REFERENCES}

Balaguer, J. - Cantavella, J. M. (2002): Tourism as a Long-Run Economic Growth Factor: The Spanish Case. Applied Economics, 34(7): 877-884.

Belloumi, M. (2010): The Relationship Between Tourism Receipts, Real Effective Exchange Rate and Economic Growth in Tunisia. International Journal of Tourism Research, 12(5): 550-560.

Brida, J. G. - Carrera, E. J. S. - Risso, W. A. (2008): Tourism's Impact on Long-Run Mexican Economic Growth. Economics Bulletin, 3(21): 1-8.

Brida, J. G. - Pulina, M. C. (2017): A Literature Review on The Tourism-Led Growth Hypothesis. Working Paper CRENOS, No.17. (Centre for North South Economic Research, University of Cagliari and Sassari, Sardinia).

Brown, L. R. - Durbin, J. - Evans, M. (1975): Techniques for Testing the Constancy of Regression Relationships over Time. Journal of the Royal Statistical Society, Series B (Methodological), 37(2): 149192.

Delivani, E. (1991): Tourism as an Alternative Engine of Growth: The Case of Greece. Unpublished Doctoral Thesis, University of York.

Delivani, E. - Nikas, C. (2013): The Greek Economy in a Kaldorian Developmental Framework: A Comment. Acta Oeconomica, 63(2): 225-228.

Drakopoulos, S. A. - Theodosiou, I. (1991): Kaldor's Approach to Greek Economic Growth. Applied Economics, 23: 1683-1689.

Dritsakis, N. (2004): Tourism as a Long-Run Economic Growth Factor: An Empirical Investigation for Greece Using Causality Analysis. Tourism Economics, 10(3): 305-316.

Elliot, B. E. - Rothenberg, T. J. - Stock, J. H. (1996): Efficient Tests of the Unit Root Hypothesis. Econometrica, 64(4): 813-836.

Engle, R. F. - Granger, C. W. J. (1987): Cointegration and Error Correction: Representation Estimation and Testing. Econometrica, 55(2): 251-276.

Granger, C. (1988): Some Recent Developments in a Concept of Causality. Journal of Econometrics, 39(1-2): 199-211.

Gunduz, L. - Hatemi, J. A. (2005): Is the Tourism-Led Growth Hypothesis Valid for Turkey? Applied Economics Letters, 12(8): 499-504.

Hare, P. (2019): Growth and Development. Acta Oeconomica, 69(S1): 215-240.

Johansen, S. (1995): Likelihood-Based Inference in Cointegrated Vector Auto-Regressive Models. New York: Oxford University Press.

Kaldor, N. (1966): Causes of the Slow Growth of the U.K. Cambridge University Press.

Katircioglu, S. T. (2009): Revisiting the Tourism-Led Growth Hypothesis for Turkey Using Bonds Test and Johansen Approach for Cointegration. Tourism Management, 30(1): 17-20.

Katrakilidis, K. - Tsaliki, P. - Tsiakis, T. (2013): The Greek Economy in a Kaldorian Developmental Framework. Acta Oeconomica, 63(1): 61-75. 
Laurenceson, J. - Chai, J. (2003): Financial Reform and Economic Development in China. Cheltenham: Edward Elgar.

Narayan, P. (2005): The Saving and Investment Nexus for China: Evidence from Cointegration Tests. Applied Economics, 37(17): 1979-1990.

National Statistical Service, Greece (2017): Labor Force Survey 1981-2015.

Ongan, S. - Demiroz, D. M. (2005): The Contribution of Tourism to the Long-Run Turkish Economic Growth. CEEOL Journal of Economics, 53(9): 880-894.

Ozturk, I. - Acaravci, A. (2011): Electricity Consumption and Real GDP Causality Nexus: Evidence from ARDL Bounds Testing Approach for 11 MENA Countries. Applied Energy, 88(8): 2885-2892.

Pesaran, M. H. - Pesaran, B. (1997): Working with Microfit 4.0: Interactive Economic Analysis. Oxford University Press.

Pesaran, M. H. - Shin, Y. (1995): Autoregressive Distributed Lag Modeling Approach to Cointegration Analysis. DAE Working Paper, No. 9514, Department of Economics, University of Cambridge.

Pesaran, M. H. - Shin, Y. (1999): An Autoregressive Distributed Lag Modeling Approach to Cointegration Analysis. In: Storm, S. (ed.): Econometrics and Economic Theory in the 20th Century: The Ragnar Frish Centennial Symposium. Cambridge University Press, Chapter 11.

Pesaran, M. H. - Shin, Y. - Smith, R. J. (2001): Bounds Testing Approaches to the Analysis of Level Relationships. Journal of Applied Econometrics, 16(3): 289-326.

Rowthorn, R. E. - Wells, J. R. (1987): De-Industrialization and Foreign Trade. Cambridge University Press.

Samitas, A. - Asteriou, D. - Polyzos, S. - Kenourgios, D. (2018): Terrorist Incidents and Tourism Demand: Evidence from Greece. Tourism Management Perspectives, 25: 23-28.

Schubert, F. S. - Brida, J. G. - Risso, W. A. (2010): The Impacts of International Tourism Demand on Economic Growth of Small Economies Dependent of Tourism. Tourism Management, 32(2): 377-385.

Shan, J. - Wilson, K. (2001): Causality between Trade and Tourism: Empirical Evidence from China. Applied Economics Letters, 8(4): 279-283.

Webster, C. - Ivanov, S. H. (2014): Tourism as a Force for Political Stability. In: Wohlmuther, C. Wintersteiner, W. (eds.): The International Handbook on "Tourism and Peace". WTO, pp. 167- 180.

Wickremasinghe, G. B. - Ihalanayake, R. (2006): The Causal Relationship between Tourism and Economic Growth in Sri Lanka, Some Empirical Evidence. Working Paper, No.2006. School of Applied Economics, Victoria University.

WTTC Travel and Tourism Economic Impact (2017).

Zortuk, M. (2009): Economic Impact of Tourism on Turkey's Economy: Evidence from Cointegration Tests. International Research Journal of Finance and Economics, 25: 231-239. 